\title{
Pseudoexfoliation syndrome and secondary cataract
}

Michael Küchle, Andrea Amberg, Peter Martus, Nhung X Nguyen, Gottfried O H Naumann

\begin{abstract}
Aim/background-The pseudoexfoliation (PEX) syndrome is frequently associated with impairment of the blood-aqueous barrier. This study analysed if this might stimulate secondary cataract following cataract extraction.

Methods-This historical cohort study included 197 eyes of 197 patients (99 with and 98 without PEX) that underwent extracapsular cataract extraction with posterior chamber lens implantation (PMMA optic) between 1985 and 1991. Secondary cataract was defined as opacification of the axial posterior capsule and decrease of visual acuity by two or more lines. Mean follow up was $\mathbf{2 3 . 8}$ months. For statistical analysis, the Kaplan-Meier method and multivariate Cox regression analysis were used.

Results-Secondary cataract was observed within 24 months in $35 \%$ (SD $7 \%$ ) of all eyes, and was significantly more frequent in eyes with PEX (45 (11)\%) than in eyes without PEX (24 (9)\%, p<0.03). Eyes with diabetes mellitus $(n=32)$ showed a significantly lower frequency of secondary cataract $(11 \quad(11) \%)$ than eyes without diabetes mellitus (39 (8)\%, p<0.01). The influences of sex, open angle glaucoma, type of cataract, surgeon, positioning of IOL, and phacoemulsification versus nuclear expression on secondary cataract did not reach statistical significance.

Conclusion-The higher frequency of secondary cataract could be considered as another potential complication of cataract surgery in eyes with PEX.

(Br f Ophthalmol 1997;81:862-866)
\end{abstract}

Pseudoexfoliation (PEX) syndrome is diagnosed by slit-lamp detection of deposits of a fibrillogranular material on the anterior lens capsule and at the pupillary margin. ${ }^{12}$ It is frequently associated with open angle glaucoma, ${ }^{3}$ melanin dispersion, ${ }^{4}$ poor pupillary dilatation, ${ }^{5}$ and may present with a specific type of PEX keratopathy. ${ }^{6}$ These features in combination with zonular instability ${ }^{7}$ predispose eyes with PEX to complications during cataract extraction. ${ }^{9-13}$

A number of studies have presented evidence of dysfunction of the blood-aqueous barrier in $\mathrm{PEX}^{14-18}$ with consecutive increase of aqueous flare ${ }^{19}$ and aqueous protein concentration. ${ }^{20}$ There is also an increasing number of reports on inflammatory reactions and fibrin formation in eyes with PEX following cataract extraction ${ }^{21-24}$ or trabeculectomy. ${ }^{25}$ Based on these observations, we hypothesised that increased and prolonged breakdown of the blood-aqueous barrier may also lead to a higher rate of secondary cataract in eyes with PEX. We performed a historical cohort study to analyse the frequency of secondary cataract in eyes with and without PEX following extracapsular cataract extraction and posterior chamber lens implantation.

\section{Methods}

From the clinical documentation data base of all patients who underwent extracapsular cataract extraction (ECCE) with implantation of a posterior chamber intraocular lens (PC-IOL) at our institution between 1985 and 1991, a sample of 99 patients with PEX and a sample of 98 patients without PEX was extracted. The control group of patients without PEX was matched for age, sex, and presence of diabetes mellitus (group matching). For those patients in whom PEX was manifest in both eyes and cataract extraction had been performed in both eyes, one eye was chosen at random. In the control group, only patients without PEX in either eye were included and one eye was chosen at random if both eyes had undergone cataract surgery. Exclusion criteria were traumatic cataract following penetrating ocular injury, history of uveitis, history of previous intraocular surgery, and intraoperative rupture of the posterior capsule and/or vitreous loss. Surgery was performed by a total of 10 surgeons, with three very experienced surgeons operating on $80 \%$ of all patients. Either nuclear expression or phacoemulsification were used. Plano convex non-heparin coated IOLs with 6.5 to $7.0 \mathrm{~mm}$ PMMA optics and propylene C-shaped haptics were implanted in $84 \%$ of eyes, and one piece biconvex all PMMA IOLs with 6.5 to $7.0 \mathrm{~mm}$ optics in the remainder of the eyes. All data were collected by reviewing the standardised patient charts and the standardised computerised surgical report. Factors analysed included presence of PEX, preoperative visual acuity, presence of open angle glaucoma, surgeon, nuclear expression or phacoemulsification, intended localisation of IOL (ciliary sulcus or capsular bag), intraoperative use of viscoelastics, intraoperative complications (rupture of posterior capsule, vitreous loss), postoperative visual acuity, development of secondary cataract, and Nd:YAG capsulotomy. The exact type of 
Table 1 Population data of 197 patients

\begin{tabular}{|c|c|c|c|c|c|c|}
\hline \multirow[b]{2}{*}{ Group } & \multirow[b]{2}{*}{ No } & \multicolumn{2}{|c|}{ Sex } & \multirow{2}{*}{$\begin{array}{l}\text { Age (years) } \\
\text { mean }(S D) \text { (range) }\end{array}$} & \multirow{2}{*}{$\begin{array}{l}\text { Follow up (months) } \\
\text { mean (SD) (range) } \\
\text { patients without secondary } \\
\text { cataract }\end{array}$} & \multirow{2}{*}{$\begin{array}{l}\text { No with diabete } \\
\text { mellitus }\end{array}$} \\
\hline & & $F$ & $M$ & & & \\
\hline All eyes & 197 & 64 & 133 & $76.5(6.6)(57-90)$ & $27.0(15.9)(3-84)$ & 32 \\
\hline PEX & 99 & 32 & 67 & $76.5(6.7)(59-89)$ & $28.4(18.6)(3-84)$ & 17 \\
\hline No PEX & 98 & 32 & 66 & $76.5(6.7)(57-90)$ & $25.9(13.5)(3-82)$ & 15 \\
\hline Diabetes mellitus & 32 & 7 & 25 & $77.4(5.4)(66-88)$ & $25.8(17.1)(8-84)$ & - \\
\hline No diabetes mellitus & 165 & 57 & 108 & $76.3(6.9)(57-90)$ & $27.3(15.6)(3-82)$ & - \\
\hline
\end{tabular}

PEX = pseudoexfoliation.

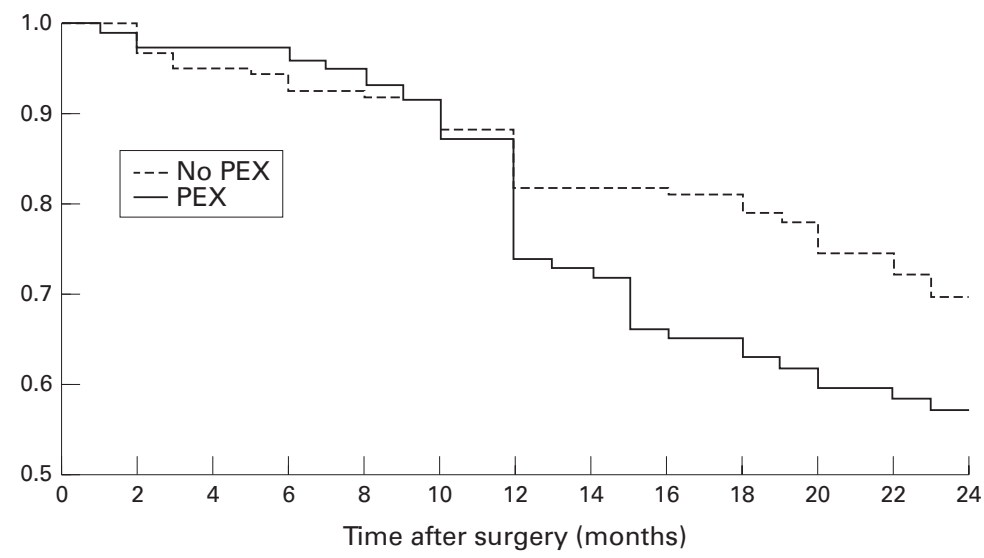

Figure 1 Kaplan-Meier survival curve of secondary cataract following extracapsular cataract extraction and posterior chamber lens implantation in eyes with or without pseudoexfoliation (PEX).

opening of the anterior lens capsule (can opener technique, letter box technique, or continuous circular capsulorhexis) was not recorded. Secondary cataract was defined as opacification of the axial posterior capsule visible at slit-lamp examination associated with a decrease of best corrected visual acuity by two or more lines. It was not differentiated between proliferative pearl-type and fibrotic secondary cataract. For patients who were not followed in our hospital, a standardised questionnaire was sent to their ophthalmologists to gain information on postoperative visual acuity and development of secondary cataract, using the above mentioned criteria.

Influence of patient age, sex, and diabetes mellitus was analysed within the PEX and non-PEX group.

For statistical analysis of secondary cataract, the Kaplan-Meier estimate for the probability of secondary cataract after 24 months was determined in the different patient groups. For all patients and separately for patients with and without PEX, additional probabilities for

Table 2 Secondary cataract according to pseudoexfoliation (PEX) and diabetes mellitus (DM)

\begin{tabular}{lrcc}
\hline Group & No & $\begin{array}{c}\text { Secondary cataract rate } \\
\text { after 24 months }{ }^{\star}(S D)\end{array}$ & p Valuet \\
\hline All eyes & 197 & $35(7) \%$ & \\
Eyes with PEX & 99 & $45(11) \%$ & $<0.03$ \\
Eyes without PEX & 98 & $24(9) \%$ & $<0.01$ \\
Eyes with DM & 32 & $11(11) \%$ & \\
Eyes without DM & 165 & $39(8) \%$ & \\
Eyes with PEX and with DM & 17 & $13 \%$ & \\
Eyes with PEX without DM & 82 & $52 \%$ & \\
Eyes without PEX with DM & 15 & $8 \%$ & \\
Eyes without PEX without DM & 83 & $26 \%$ & \\
\hline
\end{tabular}

^Kaplan-Meier estimate.

†Cox regression analysis with diabetes mellitus, PEX, patient age $(\mathrm{p}>0.9)$ and sex. $(p>0.3)$ included. secondary cataract after 6,12 , and 18 months are presented. All other rates of secondary cataract are 24 month Kaplan-Meier estimates. For the main results $95 \%$ confidence intervals (rate plus or minus $2 \mathrm{SE}$ ) are given.

Significance testing was performed using the Cox regression model with inclusion of the matching criteria.

\section{Results}

Mean patient age at surgery was 76.5 (SD 6.6) years (range 57-90 years), and there were 64 males and 133 females. Mean follow up was 23.8 (15.4) months (range 3-84 months). Diabetes mellitus was present in 32 of the 197 patients. The demographic distribution was very similar in eyes with and without PEX (Table 1).

For all eyes the secondary cataract rate was $4 \%$ (SD 3\%) after 6 months, 19 (6)\% after 12 months, 26 (6)\% after 18 months and 35 (7)\% after 24 months.

For patients without PEX the rates were 6 (5) $\%, 14(7) \%, 16(7) \%$ and $24(9) \%$, whereas $2(3) \%, 25(9) \%, 36(10) \%$ and $45(11) \%$ of the patients with PEX developed secondary cataract after 6, 12, 18, and 24 months $(\mathrm{p}<0.03$, Cox regression analysis) (Table 2$)$, with the Kaplan-Meier curve indicating that the frequency of secondary cataract started to differ between eyes with and without PEX at about 1 year after surgery (Fig 1). Eyes of patients with diabetes mellitus developed secondary cataract far less frequently (11 (11)\%) than eyes of patients without diabetes mellitus (39 (8)\%, p<0.01, Cox regression analysis) (Table 2), with the Kaplan-Meier curve indicating that the difference between eyes with and without diabetes mellitus started early in the postoperative period (Fig 2). Considering both PEX and diabetes, eyes with PEX without diabetes had the highest occurrence of secondary cataract $(52 \%)$, followed by eyes without diabetes without PEX (26\%), and by eyes with diabetes with PEX (13\%) (Table $2)$. The lowest occurrence of secondary cataract was observed in the group of eyes with diabetes without PEX (8\%).

The proportion of secondary cataract was higher for eyes with open angle glaucoma (33 (10)\% versus $27(12) \%$ ) in eyes without open angle glaucoma, nuclear cataract versus cortical cataract (41 (12)\% in eyes with nuclear cataract versus 30 (9)\% in eyes with cortical cataract), IOL placement into the ciliary sulcus (38 (12)\%) versus placement into the capsular bag (33 (10)\%), and phacoemulsification (46 (16)\%) versus nuclear expression (31 (8)\%). 


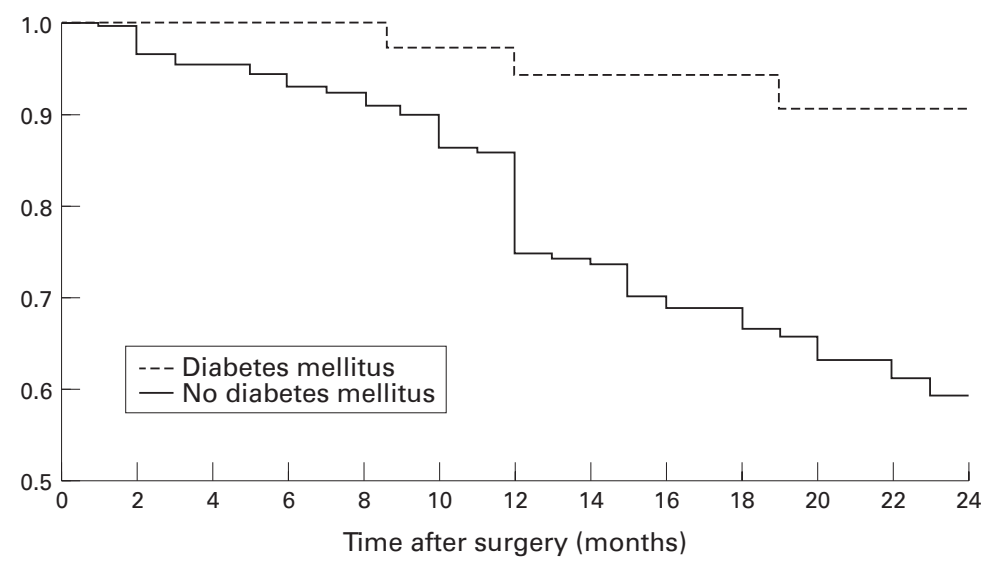

Figure 2 Kaplan-Meier survival curve of secondary cataract following extracapsular cataract extraction and posterior chamber lens implantation in eyes with or without diabetes mellitus.

Table 3 Secondary cataract according to ocular and surgical factors

\begin{tabular}{|c|c|c|c|}
\hline Factor & No of eyes & $\begin{array}{l}\text { No of eyes with } \\
\text { secondary cataract } \\
(S D)\end{array}$ & $p$ Value \\
\hline Nuclear cataract $†$ & 78 & $41(12) \%$ & $>0.4$ \\
\hline Cortical cataract $\dagger$ & 89 & $30(9) \%$ & $>0.4$ \\
\hline Presence of glaucoma & 81 & $33(10) \%$ & $>0.2$ \\
\hline Absence of glaucoma & 116 & $27(12) \%$ & \\
\hline Most experienced surgeon & 104 & $38(10) \%$ & $>0.3$ \\
\hline Less experienced surgeons & 93 & $31(10) \%$ & \\
\hline Phacoemulsification $\dagger$ & 49 & $46(16) \%$ & $>0.1$ \\
\hline Nuclear expression $\dagger$ & 146 & $31(8) \%$ & \\
\hline IOL implantation 'in the sulcus' $\dagger$ & 73 & $38(12) \%$ & $>0.2$ \\
\hline IOL implantation 'in the bag' $\dagger$ & 124 & $33(10) \%$ & \\
\hline Intraoperative use of hyaluronic acid $\dagger$ & 95 & $39(11) \%$ & $>0.9$ \\
\hline No intraoperative use of hyaluronic acid & 75 & $27(10) \%$ & \\
\hline
\end{tabular}

^Univariate Cox regression analysis, similar results after inclusion of PEX, sex, diabetes mellitus, and age.

†Factors not present or not documented in all eyes.

Table 4 Secondary cataract according to age and pseudoexfoliation (PEX)

\begin{tabular}{|c|c|c|c|c|c|c|}
\hline \multirow[b]{2}{*}{ Age group } & \multicolumn{2}{|l|}{ All eyes } & \multicolumn{2}{|l|}{$P E X$} & \multicolumn{2}{|c|}{ No PEX } \\
\hline & No of eyes & $\begin{array}{l}\text { Secondary } \\
\text { cataract } \\
(S D)\end{array}$ & $\begin{array}{l}\text { No of } \\
\text { eyes }\end{array}$ & $\begin{array}{l}\text { Secondary } \\
\text { cataract } \\
\text { (SD) }\end{array}$ & $\begin{array}{l}\text { No of } \\
\text { eyes }\end{array}$ & $\begin{array}{l}\text { Secondary } \\
\text { cataract } \\
(S D)\end{array}$ \\
\hline $57-70$ & 32 & $32 \%$ & 16 & $55 \%$ & 16 & $7 \%$ \\
\hline $71-80$ & 102 & $36 \%$ & 51 & $49 \%$ & 51 & $22 \%$ \\
\hline $81-90$ & 63 & $34 \%$ & 32 & $34 \%$ & 31 & $36 \%$ \\
\hline All ages & 197 & $35(7) \%$ & 99 & $45(11) \%$ & 98 & $24(9) \%$ \\
\hline
\end{tabular}

However, none of these differences reached statistical significance (Table 3).

The influence of patient age at surgery on development of secondary cataract seemed to be different for eyes with and without PEX. Whereas the frequence of secondary cataract decreased with increasing patient age in PEX (from $55 \%$ in patients younger than 71 years to $34 \%$ in patients older than 80 years), it apparently increased with increasing patient age in patients without PEX (from $7 \%$ in patients younger than 71 years to $36 \%$ in patients older than 80 years) (Table 4 ).

\section{Discussion}

Opacification of the posterior lens capsule after cataract surgery is a major medical and socioeconomic problem. Formation of secondary cataract may result from two mechanisms with many pathogenetic factors still poorly understood. ${ }^{26-28}$ Migration of lens epithelial cells onto the posterior lens capsule leads to the proliferative variant with formation of Elschnig pearls, or metaplasia of lens epithelial cells into myofibroblasts is followed by fibrosis and contracture of the posterior capsule. The reported incidence of secondary cataract after extracapsular cataract surgery varies widely, ranging between $14 \%$ and $53 \%$ without PC-IOL implantation and between $7 \%$ and $50 \%$ with PC-IOL implantation. ${ }^{29-33}$ It is difficult to compare the rates of secondary cataract formation in various studies because of high variations in follow up time, definition of secondary cataract, patient age, surgical techniques, and type of intraocular lenses.

Many factors have been reported to influence development of secondary cataract, most notably patient age, ${ }^{34}$ type of cataract, ${ }^{35}$ intraocular lens design including presence of laser ridges, ${ }^{36-40}$ intraocular lens placement, ${ }^{41}$ phacoemulsification, ${ }^{42}$ and intraocular lens material. $^{43} 44$

Clinical reports on inflammatory reactions and fibrin formation in eyes with PEX following cataract extraction ${ }^{21-23}$ appear to be related to ultrastructural changes of the morphological correlates of the bood-aqueous barrier. Accordingly, electron microscopy and tracer studies have demonstrated alterations of the endothelial cells and basement membrane of the iris vessels ${ }^{45-48}$ and the non-pigmented ciliary body epithelium. ${ }^{47} 48$ In addition, noninvasive laser flaremetry has demonstrated postoperative breakdown of the blood-aqueous barrier, which has been shown to be significantly increased in eyes with PEX after cataract extraction with PC-IOL implantation, ${ }^{24}$ following trabeculectomy, ${ }^{25}$ and following argon laser trabeculoplasty. ${ }^{49}$

We were able to confirm our hypothesis that eyes with PEX have a higher frequency of secondary cataract. Several possible mechanisms may account for this observation. Firstly, intraoperative factors may be responsible for the higher rate of secondary cataract. Poor intraoperative pupillary dilatation, weak zonular support, posterior synechiae, ${ }^{50}$ and corneal decompensation $^{6}$ may force the surgeon to minimise removal of equatorial lens cortex and lens epithelium and to reduce polishing of the posterior capsule, thus predisposing eyes to proliferation of lens epithelium and formation of secondary cataract. However, the observation that secondary cataract increased only 1 year after cataract surgery (Fig 1) in eyes with PEX indicates that intraoperative factors may be of lesser importance. Secondly, impairment of the blood-aqueous barrier and prolonged postoperative barrier breakdown in PEX may provide a protein rich 'culture medium' with plasma factors and growth factors, ${ }^{51}$ thus supporting the proliferation of residual lens epithelium cells. However, the fact that eyes with diabetes mellitus showed a reduced number of secondary cataracts in our study rather speaks against a direct correlation between defects of the bloodaqueous barrier and formation of secondary cataract, as blood-ocular barrier breakdown is frequently seen in diabetic patients. ${ }^{52}{ }^{53}$ Thirdly, weakened zonular support may lead to focal areas of zonulolysis with increased capsular folds 
Table 5 Pseudoexfoliation as a potential risk factor in cataract surgery

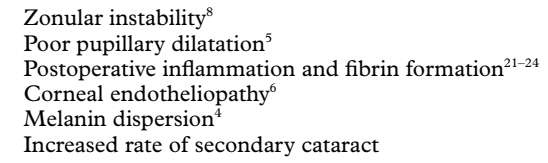

and subsequent facilitated migration of lens epithelium or fibrotic changes. Finally, it has been demonstrated that intraocular hypoxia exerts a strong stimulatory effect on proliferation of intraocular cells. ${ }^{54}$ As anterior chamber hypoxia has been demonstrated in eyes with $\mathrm{PEX}^{55}$ this may induce proliferation of lens epithelium and cause secondary cataract.

An unexpected and surprising finding of the present study was the reduced incidence of secondary cataract in eyes of patients with diabetes mellitus, as we had rather expected secondary cataract to be more frequent in diabetic eyes as a result of the impairment of the blood-ocular barriers. However, our data have to be cautiously interpreted with regard to diabetes mellitus and secondary cataract, as this study was not designed to evaluate the effect of diabetes mellitus on the frequency of secondary cataract; the number of eyes with diabetes was small $(n=32)$; and we did not analyse the diabetic population in our study in detail with regard to stage of diabetic retinopathy and other factors. Therefore, we cannot exclude the possibility that our sampling scheme may have induced an overestimation of the role of diabetes mellitus. Knorz et $a l^{56}$ and Tetz et $a l^{57}$ observed similar findings of decreased incidence of secondary cataract in diabetics independently, whereas the contrary has also been reported. ${ }^{58}$

The influence of other factors-intended location of IOL, phacoemulsification, surgeon, and type of cataract-did not reach statistical significance in our study with regard to the occurrence of secondary cataract. However, these results must also be seen in light of the fact that this study was not designed specifically to evaluate the effect of these factors on secondary cataract.

PEX may be associated with potential serious ocular complications including rapidly progressive open angle glaucoma, ${ }^{3}$ corneal decompensation secondary to PEX keratopathy, ${ }^{6}$ spontaneous subluxation or luxation of the lens, ${ }^{59}$ cilio-lenticular angle closure glaucoma,${ }^{60}$ and complications during cataract surgery. From the results of our study, it appears that secondary cataract should be added to the already long list of complications of cataract surgery in PEX (Table 5). Thus, in eyes with PEX, surgeons should probably try to take intraoperative measures to reduce remaining lens epithelium and minimise the chance of secondary cataract formation, and patients with PEX should probably be informed of their increased risk of developing secondary cataract.

Presented in part at the Annual Meeting of the American Academy of Ophthalmology, Atlanta, Georgia, 29 October to 2 November 1995.
1 Prince AM, Ritch R. Clinical signs of the pseudoexfoliation syndrome. Ophthalmology 1986;93:803-7.

2 Tetsumoto K, Schlötzer-Schrehardt U, Küchle M, Dorfler S, Naumann GO. Precapsular layer of the anterior lens capsule in early pseudoexfoliation syndrome. Graefes Arch Clin Exp Ophthalmol 1992;230:252-7.

3 Brooks AMV, Gillies WE. The presentation and prognosis of glaucoma in pseudoexfoliation of the lens capsule. Ophthalmology 1988;95:271-6.

4 Krause U, Helve J, Forsius H. Pseudoexfoliation of the lens capsule and liberation of iris pigment. Acta Ophthalmol 1973;51:39-46.

5 Carpel EF. Pupillary dilation in eyes with pseudoexfoliation yndrome. Am f Ophthalmol 1988;105:692-4.

6 Schlötzer-Schrehardt UM, Dörfler S, Naumann GOH. Corneal endothelial involvement in pseudoexfoliation syndrome. Arch Ophthalmol 1993;111:666-74.

7 Allen JS. Zonular dialysis in pseudoexfoliation syndrome. Arch Ophthalmol 1987;105:1318-9.

8 Schlötzer-Schrehardt U, Naumann GOH. A histopathologic study of zonular instability in pseudoexfoliation syndrome. Am 7 Ophthalmol 1994;118:730-43.

9 Naumann GOH, Erlanger Augenblätter-Group. Exfoliation syndrome as a risk factor for vitreous loss in extracapsular cataract surgery. Preliminary report. Acta Ophthalmol 1986;66(Suppl 184):129-31.

10 Guzek JP, Holm M, Cotter JB, Cameron JA, Rademaker WJ, Wissinger $\mathrm{DH}$, et al. Risk factors for intraoperative complications in 1000 extracapsular cataract cases. Ophthalmology 1987;94:461-6.

11 Skuta GL, Parrish RK, Hodapp E, Forster RK, Rockwood EJ. Zonular dialysis during extracapsular cataract extraction in pseudoexfoliation syndrome. Arch Ophthalmol tion in pseudo

12 Naumann GOH, Küchle M, Schönherr U, 'Erlanger Augenblätter-Gruppe'. Pseudoexfoliationssyndrom als Risikofaktor für Glaskörperverlust bei der extrakapsulären Kataraktextraktion. Fortschr Ophthalmol 1989;86:543-5.

13 Lumme P, Laatikainen L. Exfoliation syndrome and cataract extraction. Am f Ophthalmol 1993;116:51-5.

14 Sampaolesi R. Neue Untersuchungen über das PseudoKapselhäutchen-Glaukom (Glaucoma capsulare). Ber Dtsch Ophthalmol Ges 1960;62:177-83.

15 Vannas A. Vascular changes in pseudoexfoliation of the lens capsule and capsular glaucoma. A fluorescein angiographic and electron microscpic study. Graefes Arch Clin Exp Ophthalmol 1972;184:248-53.

16 Johnson DH, Brubaker RF. Dynamics of aqueous humor in the syndrome of exfoliation with glaucoma. Am $\mathcal{f}$ Ophthalmol 1982;93:629-34.

17 Brooks AMV, Gillies WE. Fluorescein angiography and fluorophotometry of the iris in pseudoexfoliation of the ens capsule. Br F Ophthalmol 1983;67:249-54

18 Tada H, Takahashi N, Kimura Y. Anterior segment fluorophotometry in pseudoexfoliation syndrome. $\mathcal{F p n ~} \mathcal{7}$ Clin Ophthalmol 1988;42:698-9.

19 Küchle M, Nguyen NX, Horn F, Naumann GOH. Quantitative assessment of aqueous flare and aqueous 'cells' in pseudoexfoliation syndrome. Acta Ophthalmol 1992;70: 201-8.

20 Küchle M, Ho ST, Nguyen NX, Hannappel E, Naumann GO. Protein quantification and electrophoresis in aqueous humor of pseudoexfoliation eyes. Invest Ophthalmol Vis Sci 1994;35:748-52.

21 Wålinder PEK, Olivius EOP, Nordell SI, Thorburn WE. Fibrinoid reaction after extracapsular cataract extraction and relationship to exfoliation syndrome. $\mathcal{F}$ Cataract Refract Surg 1989;15:526-30.

22 Zetterström C, Olivestedt G, Lundvall A. Exfoliation syndrome and extracapsular cataract extraction with implantation of posterior chamber lens. Acta Ophthalmol 1992;70:85-90

23 Drolsum L, Davanger M, Haaskjold E. Risk factors for an inflammatory response after extracapsular cataract extraction and posterior chamber IOL. Acta Ophthalmol 1994;72: tion and $21-6$.

24 Schumacher S, Nguyen NX, Küchle M, Naumann GOH. Quantification of aqueous flare after phacoemulsification with intraocular lens implantation in pseudoexfoliation syndrome. Invest Ophthalmol Vis Sci (Suppl) 1995;36:797.

25 Küchle M, Nguyen NX, Naumann GOH. Quantification of aqueous flare after trabeculectomy: pseudoexfoliation versus primary open-angle glaucoma. Ophthalmology (Suppl) 1994;101:129.

26 Kappelhof JP, Vrensen GFJM. The pathology of aftercataract. A minireview. Acta Ophthalmol Suppl 1992;205: $13-24$.

27 Green WR, McDonnell PJ. Opacification of the posterior lens capsule. Trans Ophthalmol Soc UK 1985;104:727-39.

28 Apple DJ, Solomon KD, Tetz MR, Assia EI, Holland EY, Legler UF, et al. Posterior capsule opacification. Surv Ophthalmol 1992;37:73-116.

29 Binkhorst CD. Five hundred planned extracapsular cataract extractions with irido-capsular and iris-clip lens implantation in senile cataract. Ophthalmic Surg 1977;8:37-44.

$30 \mathrm{Nishi}$ O. Incidence of posterior capsule opacification in eyes with and without posterior chamber lenses. $\mathcal{F}$ Cataract Refract Surg 1986;12:519-22.

31 Moisseiev J, Bartov E, Schochat A, Blumenthal M. Long-term study of the prevalence of capsular opacification following extracapsular cataract extraction. F Cataract Refract Surg 1989;15:531-3. 
32 Frezzotti R, Caporossi A. Pathogenesis of posterior capsular opacification. Part I. Epidemiological and clinico-statistical data. F Cataract Refract Surg 1990;16:347-52.

33 Balmer A, Andenmatten R, Hiroz C-A. Complications de la chirurgie de la cataracte. Etude rétrospective de 1304 cas. Klin Monatsbl Augenheilkd 1991:198:344-6.

34 Maltzman BA, Haupt E, Notis C. Relationship between age at time of cataract extraction and time interval before capsulotomy for opacification. Ophthalmic Surg 1989;20:3214 .

35 Argento C, Nunez E, Wainsztein R. Incidence of postoperative posterior capsular opacification with types of senile cataracts. F Cataract Refract Surg 1992;18:586-8.

36 Sterling S, Wood TO. Effect of intraocular lens convexity on posterior capsule opacification. F Cataract Refract Surg 1986;12:655-7.

37 Santos BA, Del Monte MA, Pastora R, O'Donell FE. Comparative study of the effects of optic design on lens epithe-
lium in vitro. $\mathcal{F}$ Cataract Refract Surg 1987;13:127-30.

38 Sellman TR, Lindstrom RL. Effect of a plano-convex posterior chamber lens on capsular opacification from Elschnig rior chamber lens on capsular opacification from Elschnig
pearl formation. 7 Cataract Refract Surg 1988;14:68-72.

39 Setty SS, Percival SPB. Intraocular lens design and the inhiSetty SS, Percival SPB. Intraocular lens design and the
bition of epithelium Br 7 Ophthalmol 1989;73:918-21.

40 Born CP, Ryan DK. Effect of intraocular lens optic design on posterior capsular opacification. 7 Cataract Refract Surg 1990;16:188-92.

41 Vilhjalmsson GA, Lucas BC. Zur Nachstarinzidenz sulkusversus kapselsackfixierter Hinterkammerlinsen. Klin Monatsbl Augenheilkd 1992;200:167-70.

42 Arneodo J. La cataracte secondaire après extracapsulaire mécanisée ou phacoemulsification. 7 Fr Ophtalmol 1989;12: 287-90.

43 Milauskas AT. Posterior capsule opacification after silicone lens implantation and its management. $\mathcal{F}$ Cataract Refract Surg 1987;13:644-8.

44 Sheperd JR. Capsular opacification associated with silicon implants. $\mathcal{F}$ Cataract Refract Surg 1989;15:448-50.

45 Ringvold A. Electron microscopy of the wall of iris vessels in eyes with and without exfoliation syndrome (pseudoeyes with and without exfoliation syndrome (pseudoAnat 1969;348:328-41.

46 Konstas AGP, Marshall GE, Lee WE. Iris vasculopathy in exfoliation syndrome. An immunocytochemical study. Acta Ophthalmol 1991;69:472-83.

47 Schlötzer-Schrehardt U, Dörfler S, Naumann GOH Immunohistochemical localization of blood-aqueous bar- rier dysfunction in eyes with pseudoexfoliation syndrome. Invest Ophthalmol Vis Sci (Suppl) 1992;33:731.

48 Küchle M, Vinores SA, Mahlow J, Green WR. Bloodaqueous barrier in pseudoexfoliation: Evaluation by immunohistochemical staining of endogenous albumin. Graefes Arch Clin Exp Ophthalmol 1996;234:12-8.

49 Mermoud A, Pittet N, Herbort CP. Inflammation patterns after argon laser trabeculoplasty measured with the laser flare meter. Arch Ophthalmol 1992;110:368-70.

50 Dark AJ. Cataract extraction complicated by capsular glaucoma. Br f Ophthalmol 1979;63:465-8.

51 Schlötzer-Schrehardt U, Dörfler S, Naumann GOH. Expression of growth factors in the human ciliary epithelium. Invest Ophthalmol Vis Sci Suppl 1993;34:825.

52 Cunha-Vaz J, Abreu JRF de, Campos AJ, Figo GM. Early breakdown of the blood-retinal barrier in diabetes. $\mathrm{Br} 7$ Ophthalmol 1975;59:649-56.

53 Küchle M, Schönherr U, Nguyen NX, Steinhauser B, Naumann GO. Quantitative measurement of aqueous flare and aqueous 'cells' in eyes with diabetic retinopathy. Ger $\mathcal{F} \mathrm{Oph}$ thalmol 1992;1:164-9.

54 Zagorski Z, Gossler B, Naumann GOH. Effect of low oxygen tension on the growth of bovine corneal endothelial cells in vitro. Ophthalmic Res 1989;21:440-2.

55 Helbig H, Schlötzer-Schrehardt U, Noske W, Kellner U, Foerster MH, Naumann GO. Anterior-chamber hypoxia and iris vasculopathy in pseudoexfoliation syndrome. Ger $\mathcal{F}$ Ophthalmol 1994;3:148-53.

56 Knorz MC, Soltau JB, Seiberth V, Lorger C. Incidence of posterior capsule opacification after extracapsular cataract extraction in diabetic patients. Metab Pediatr Syst Ophthalmol 1991; 14:57-8.

57 Tetz M, Lehrer I, Klein U, Völcker HE. Cataracta secundaria bei Diabetes mellitus. Klin Monatsbl Augenheilkd 1994;205:395

58 Ionides A, Dowler JGF, Hykin PG, Rosen PH, Hamilton AM. Posterior capsule opacification following diabetic extracapsular cataract extraction. Eye 1994;8:535-7.

59 Freissler K, Küchle M, Naumann GOH. Spontaneous dislocation of the lens in pseudoexfoliation syndrome. Arch Ophthalmol 1995;113:1095.

60 Lippe I von der, Küchle M, Naumann GOH. Pseudoexfoliation syndrome as a risk factor for acute ciliary block angle closure glaucoma. Acta Ophthalmol 1993;71:277-9. 